\title{
MIRRORING THE FACE OF CHRIST
}

\section{Răzvan BRUDIU*}

\begin{abstract}
The mystery of the Face of Christ was a religious, anthropological, theological and political stake in the first eight Christian centuries and has had secularised echoes up to our times (see the anti-icon fight of many humanist leaders and the elimination of the icons from the public space).The present study intends to highlight the fact that, in the Byzantine Empire, the Christians became confessors and martyrs of the image of Christ, refusing the political compromise of the imperial power, reconstituted by the iconomach emperors, based on a powerful reform, iconoclasm. Byzantine iconoclasm returned to the Constantinian image of Christ only as the symbol of the Cross, a presence through a representation. An imminent conclusion is the following: the apparent conflict between image and sign and between icon and cross was in fact the desire of the iconomach emperors to substitute the image of Christ for their own images - the emperors wanted to become living images of Divinity on earth.The 7th Ecumenical Council and later, St. Theodore the Studite and Patriarch Nicephorus proved and established that the icon is part of the Apostolic Tradition and of the universal Church and that in fact the icon affirms and re-actualizes the Incarnation as mystery and revelation and also the deification of man in Christ. The Holy Fathers indicate that seeing the Face of Christ is fulfilled only in the light of the Holy Spirit and the deification of the human being starts with this face. In conclusion, the mystical experience is always and every time an iconographic experience: the mystery of the human Face of Christ is mirrored in the mystery of the man in Christ.
\end{abstract}

Keywords: iconoclasm, icon, Incarnation, Seventh Ecumenical Council, Church.

Ph.D., Junior Lecturer, Faculty of Orthodox Theology at "1 Decembrie 1918" University, Alba Iulia, Romania. 


\section{Preliminaries}

The mystery of the face of Christ is a contemporary profound theme in the Orthodox tradition and theology. The present study intends to highlight the fact that the problems and the controversies in the iconoclast period between the $7^{\text {th }}$ and the $9^{\text {th }}$ centuries have had echoes and have caused secularized attacks up to our times. Without being critical or moralistic, we witness today more than ever a fight against the Church and the clergy, constantly led in an organized way by massmedia or by the so-called personalities in the Romanian public space. They attack the idea of icons and the presence of icons in public institutions, because they are considered a real discrimination by those disagreeing with the Christian religious symbols and signs, consequently suggesting that these spaces should remain neutral. From this point of view, the vision of many modern sociologists and psychologists puts forward the idea that the presence of the icon in public spaces is a strong form of inequality.

Following the historical line of events, the mystery of the face of Christ and the destiny of the icons in the iconoclast period reach the climax of the confession of faith of the Christian Church, but, at the same time, bring to light the problem of the Byzantine imperial theocracy, together with its unjust and incorrect inferences between temporality and spirituality, between state and Church, that Byzantine symphony (represented iconographically by the bicephalous eagle) that brought advantages and, at the same time, disadvantages to the Church.

If the Christians became martyrs during the first centuries because of their refusal of religious images associated with the ancient polytheism and the imperial cult, in Byzantium, the Christians became witnesses and martyrs of the face of Christ, as they did not agree with the theocratic ideas of the imperial power, formulated by the iconomach emperors on the basis of the ample reform of iconoclasm ${ }^{1}$.

Whereas during the iconoclast period the fight for the existence of

${ }^{1}$ Ioan I. ICĂ jr., "Misterul Feței lui Hristos în tradiția ortodoxă” (The Mystery of Christ's Face in the Orthodox Tradition), in the volume Omagiu Părintelui academician Dumitru Popescu (Homage to Reverend Father academician Dumitru Popescu), Alba Iulia, Reîntregirea Publishing House, 2005, p. 87. 
the face of Christ was defended by the dogma of the Humanisation of God (God became human), nowadays is discussed its result (so that man should become god). The contemporary phenomenon of the iconoclasm does not insist too much on the idea of negating the image, preferring instead the idea of distorting and destroying it, because it is no longer understood by its opponents as a vital place in the spiritual and liturgical life of the Church ${ }^{2}$.

\section{The substitution of the Face of Christ during the iconoclast period}

The iconoclasm was a turning point in the history of the Church. We must determine from the start the political and social context of those times in the Byzantine Empire. The historical data show that the inhabitants of the empire were confronted with the pressure of the Islamic power and of the barbarian invasions and, against these dangers, the emperors organized a program for the military and political reconfiguration of the empire, intending to establish a theocratic model, following the Constantinian model ${ }^{3}$.

The iconomach emperors had the tendency to replace the image of Christ with the sign of the Cross, a type of presence through representation. The elimination of the image of Christ from the symbolic scene of the imperial palace of Constantinople clearly shows the intention of replacing the face of Christ with something else. The place of the icons was taken by the own images of the emperors, who wanted to be the unique living images of the Divinity on Earth. Those fighting these imperial deviations and manipulations of the cult of the icons were the women and the monks, who paid the price of confession and martyrdom for the re-establishment of the spiritual equilibrium in Church $^{4}$. Emperor Constantine $\mathrm{V}$ tried to justify iconoclasm theologically, transferring it with subtlety in the field of the Christological themes and forcing, through the Council of Hieria (754)

${ }^{2}$ Leonid OuSPENSKY, "Icoana, vedere a lumii duhovnicești" (The Icon, Vision of the Spiritual World), in the volume Ce este icoana? (What is the Icon?), rom.transl. by Vasile Manea, Alba Iulia, Reîntregirea Publishing House, 2005, p. 32.

${ }^{3}$ Ioan I. ICĂ jr., op. cit., p. 88.

${ }^{4}$ Ibidem, pp. 88-89. 
an ecclesial legitimation from a servile and obedient episcopacy 5 .

It is amazing to see how, in spite of opposing orientations, both the iconodules and the iconomachs came to the same result: the condemnation. In the first case, they wanted to promote the conception according to which the icon must be of the same nature with the original; in the second case, the conception to which the icon is infinitely far from the original. These were the two obvious and clear tendencies in the conclusions of the Council of Hieria. Emperor Constantine $\mathrm{V}$ was more interested in the sacred presence of the model in its material representation, whereas the theology of the Council in 754 adopted rather a Neo-platonic direction of thinking ${ }^{6}$.

After a period of cruelty during the reign of Constantine $\mathrm{V}$, continued for a short while by Leon IV, the succession to the throne went to Empress Irina who, with the help of the Patriarch Tarasius of Constantinople and with the help of Rome, through the direct involvement of Pope Adrian I, convoked a Council in Nicea, as a counter-reaction to the iconoclast council of Hieria ${ }^{7}$.

The text of the Council of Nicea focuses, on the one hand, on affirming the belonging of icons to the Apostolic Tradition of the Universal Church, and, on the other hand, on the idea that icons affirm and reactualize the act of the Humanisation of Christ and represent, at the same time, the liturgical and spiritual life of the $\mathrm{Church}^{8}$.

During the $8^{\text {th }}$ and the $9^{\text {th }}$ centuries, the Church conferred a dogmatic base to the idea of the face of Christ and of icons, highlighting a fundamental truth of faith - the Humanisation of God. Saint John of Damascus is the theologian who achieved a synthesis of the theology of the Face of Christ and of icons. His theology became the official teaching of the Church.

This saint defended in his writings the icon and the dogma of the Incarnation as well:

"It is clear that when you contemplate God, who is a pure spirit,

5 Ibidem, p. 88.

${ }^{6}$ Christoph Schönborn, Icoana lui Hristos (The Icon of Christ), rom.transl. by Vasile

Răducă, București, Anastasia Publishing House, 1996, pp. 127-128.

7 Ibidem, p. 89.

${ }^{8}$ Ibidem, p. 90. 
becoming man for your sake, you will be able to clothe Him with the human form. When the Invisible One 9 becomes visible to flesh, you may then draw a likeness of His form. When He, who is a pure spirit, without form or limit, immeasurable in the boundlessness of His own nature, existing as God, takes upon Himself the form of a servant in substance and in stature, and a body of flesh, then you may draw His likeness, and show it to anyone willing to contemplate it" $"$

An important contribution of Saint John of Damascus related to the theology of the icon is the clarification of the notion of face. He enumerates five categories: 1. the face of one essence, which is perfectly achieved only in the Son; 2. the original faces of all the things in God; 3 . the things seen to the extent in which they are faces of the unseen realities and represent these bodily, for the embodied things to lead us to the recognition of the truths without a body. 4. the present faces may be faces of the future things to come; 5 . the images of the past whose memory we intend to keep. These may be kept in written or through painting (the icons). In this last category, Saint John of Damascus mentions another category, the category of the man as face of God, as imitation of Himself ${ }^{10}$.

The origin of the image is divine, because the original image is identical: invisible but supreme image, model for any image. The image is at the beginning, because the Word has been at the beginning, and the Word is the image, the face of God. When entering the field of the iconic thinking, the Orthodox theology and tradition facilitate the paradigm of the Holy Trinity, which may be enounced as: the Father, the Face and the Voice ${ }^{11}$.

\section{The humanisation of the Face in the Orthodox Theology}

The Orthodox Theology and Tradition present the humanisation as revelation and mystery, appearance and hiding, cataphasis and apophasis, knowledge and ignorance. This truth is revealed through the

\footnotetext{
${ }^{9}$ Saint John of Damascus, Cultul sfintelor icoane (The Veneration of the Holy Icons), rom.transl. by Dumitru Fecioru, București, Cernica, 1937, pp. 7-8.

${ }^{10}$ Christoph SCHÖNBORN, op. cit., pp. 149-150.

${ }^{11}$ Marie-José MondzaIn, Imagine, icoană, iconomie (Image, icon, iconomy), rom.transl. by Adrian Alexandrescu, București, Sophia Publishing House, p. 111.
} 
presence of the iconostasis that hides the sanctuary from the eyes of the believer. The Roman Catholic Church, the Protestants and NeoProtestants, do not have an iconostasis, and the altar is an open space. This proves that, for the western theology, the humanisation means only revelation, whereas, for the Orthodox Theology, it means revelation and mystery at the same time ${ }^{12}$.

Christ is the One who re-established the human face in His humanity and showed the real face of God. He has a real human face that, ultimately, is the face of God, a living icon of God, made not by the human hand. The humanisation of Christ is the strongest argument of the dogma of venerating icons. Understanding the being of the icon requires as fundamental principle the humanisation of the Face, which reveals what given to the humans during his creation. After his creation, man has the face of God and is the living icon of God. Through the fall of man, the face has suffered. The initial iconicity is restored in man through the power and the reality of the humanisation of the Face ${ }^{13}$.

The dogma of the humanisation of the face has two fundamental aspects: God became human so that man can become god (St. Irenaeus of Lyons, St. Athanasius the Great of Alexandria). We see how God comes into the world and participates in its history, but, at the same time, we also see the aims of this humanisation, which are the theosis of man and the transfiguration of the entire creation ${ }^{14}$. In this respect, Teodor Baconsky underlines the fact that the Humanisation of the Face is not a scientifical truth, which can be demonstrated in an experimental way, but it is the truth of faith that gave substance to all our defining truths. If this synergy between God and man is not achieved, then our postmodern rationality unites the human species only in its horizontal dimension and leads it not to theosis, but to beastly vulgarity ${ }^{15}$.

12 George REMETE, "Ființa și credința" (The Faith and the Being), in the volume Ideea de ființă (The Idea of Being), București, Academia Română Publishing House, pp. 606-607.

${ }^{13}$ Serghei Bulgakov, Icoana si cinstirea sfintelor icoane (The Icon and the Veneration of the Holy Icons), rom.transl. by Paulin Lecca, București, Anastasia Publishing House, 2000, pp. 118-119.

14 Leonid OusPensky, Teologia icoanei în Biserica Ortodoxă, rom.transl. by Teodor Baconsky, București, Anastasia Publishing House, 2009, p. 144.

15 Teodor BACONSKY, Facebook: Fabrica de narcisism (Facebook: The Factory of 
Seeing face to face the age to come belongs to the Person of the Humanised Face. Thus, the Holy Fathers mention that it is not the divine nature, nor the human nature, but the face of the hypostasis of Christ that is showed to us on the icons. The cult of the icons is the beginning of seeing The Eighth Day. The face of Christ can be painted, because His face, according to the human face, is identical to the unseen, according to the divine face, both achieving the two aspects of the unique Hypostases - Image ${ }^{16}$.

Because the Son of God took a human face, God became visible as person, revealing through His humanity, His Divinity, distinct from it. Only the humanisation made visible, through the undefined human face, the unspoken but real infinite of the divine person of the Word. We paint Christ in order to remember the human face of God who was one on Earth and also in order to make His face visible through art, a face that exists now and which will be in an eternal connection with us, proving that our faces will resurrect for an eternal life together with Him. Through the presence of His face in the icon, we raise our mind and soul toward His unseen but alive face, so that when we meet His face in eternity, we will be familiarized and easily recognise it ${ }^{17}$.

Christ became not just a simple man, but the man in general (universal), meaning that $\mathrm{He}$ assumed the entire human nature, according to which He is seen, touched and circumscribed, he is hungry and thirsty, tired and rested. In spite of all these, He is not a simple man, but God himself made man. At the same time, despite being humanised God, with body from the Theotokos, He is uncircumscribed. We are in the presence of a mystery of the Economy, the coming together of the divine and human nature in the unique hypostasis of the Logos ${ }^{18}$.

Leonid Ouspensky, in Theology of the Icon, observes that, on the

Narcisism), București, Humanitas Publishing House, 2015, p. 11.

16 Paul Evdokimov, Arta icoanei, o teologie a frumusetii (The Art of the Icon, Theology of Beauty), rom.transl. by Grigore Moga, București, Sophia Publishing House, 2014, p. 205.

17 Dumitru Stăniloae, Teologia Dogmatică Ortodoxă (The Orthodox Dogmatic Theology), vol. III, Fourth Edition, București, Institutul Biblic și de Misiune Ortodoxă Publishing House, 2010, pp. 352-353.

18 Saint Theodore the Studite, Iisus Hristos-Prototip al icoanei Sale (Jesus ChristPrototype of His Icon), rom.transl. by Ioan I. Ică jr., Alba Iulia, Deisis Publishing House, 1994, p. 77. 
Sunday of Orthodoxy, the kontakion does not address a trinitarian Person, but the Theotokos. The humanisation of Christ is without a doubt the fundamental dogma of the Christian faith. Nevertheless, the confession of this dogma is possible only if we do confess the Theotokos as the real Mother of God. The negation of the human face of God means to negate the divine maternity and, in the end, to negate the meaning of our deliverance ${ }^{19}$. Following a logical line, we may affirm that the existence and the honouring of Christ involvethe role of the Mother of God, because, through the consent given to the Archangel Gabriel, she made possible for the visibility and representative of God.

The Holy Fathers highlight the idea that the representation of God - the Man is based on the very possibility of representing the human nature of His Mother. Indeed, Christ is born from an unseen Father, consequently, He cannot have a face. However, the moment He was born from a visible Mother, He has a face that corresponds to that of His Mother. If we could not paint Christ in icons, the logical deduction would be that Christ was born only from the Father, meaning that $\mathrm{He}$ was not humanised. This syllogism would overthrow and destroy the entire economy of our salvation ${ }^{20}$.

The economy is unseparated from the virginal conception of the human body of the Word. The bodily economy of the birth is the hypostasized manifestation of the being that needed a means of visible manifestation; this was aimed by Salvation and may not be conceived outside resemblance. The body of the Theotokos brought into the world the manifestation of God in an image. The Theotokos gives birth to the Face and the Father gives Him the Name. These aspects of the economy of humanisation are entirely found in the iconic economy ${ }^{21}$.

\section{The Transfiguration in the Orthodox Tradition}

In the Orthodox tradition, the entire economy of the Humanisation of God and of man's theosis in Christ is understood in the terms of an iconography, whose paradigm is the Transfiguration. Father Ioan Ică Jr. refers to

\footnotetext{
${ }^{19}$ Leonid USPENSKY, op. cit., p. 152.

${ }^{20}$ Ibidem.

${ }^{21}$ Marie-José MondZAin, op. cit., p. 49.
} 
about this mystic icon-photo-graphic, intending to show the apostolic reality that lying at the heart of the Tradition of the Church, in its vertical meaning of receiving the Holy Spirit, not only as horizontal conveyance of traditions. The grace of the Holy Spirit paints with light on the human face the invisible image of God, transforming the saints in mystical reflections of Christ, thus integrating them in the imagological trinitarian circuit: being the Son of God is the same thing as being the image of God. Only in this process of reciprocal reflection - resemblance does the real knowledge of the mystery of the human Face of God and of man's face in eikon and light take place $^{22}$.

The troparion of Transfiguration says: “(...) revealing Your glory to Your disciples as far as they could bear it". It is reminded here the fact that the vision requires a gift that transfigures the sight. At the same time, we see the unique theandric reality in Hypostasis of the Face made human, which is revealed to the disciples. The Face of God Who is unseen becomes visible through the Image of the Face. This Taboric image demonstrates and conditions dogmatically the icon of Christ and the icon in general $^{23}$. Through His Transfiguration, Christ shows the disciples the archetypal beauty of the image, so that Adam's dark nature starts shining again ${ }^{24}$.

The iconography of this feast transposes us in an eschatological time and space. The appearance or the white light of Christ suggests that $\mathrm{He}$ is the real light of the world. The Greek term metamórphōsis literally means a change of the figure or of the form. Analysing the term, the theologians observe that such a change, on this occasion, is unimaginable. If Christ had changed His form, He would not have been Himself anymore, and the apostles would not have recognised Him anymore. Hence, on the Tabor Mountain, the change was that of the light and not of the form ${ }^{25}$. Here we may observe what the Western scholastic theology refuses to admit: the distinction between the divine nature and its uncreated manifestation, as energy and light.

${ }^{22}$ Ioan I. ICĂ jr., op. cit., p. 98.

${ }^{23}$ Paul Evdokimov, op. cit., p. 206.

${ }^{24}$ Ioan I. ICĂ jr., op. cit., p. 100.

25 Tomáš ŠPIDLík, Credință și icoană (Faith and Icon), rom.transl. by Ioan Milea, Cluj Napoca, Dacia Publishing House, 2002p. 41. 
What is relevant to the feast of the Transfiguration of the Lord is not so much the fact that He was glorified and that we knew His glory. His glory is infinitely greater than the one seen by the small circle of the Apostles. Nevertheless, this small glory did not come from the glory of God, but from His human deified body ${ }^{26}$. If we approach attentively the canon of this feast, we may easily observe the fact that, the Transfiguration was not the change of Christ, but of the Apostles, who were illuminated by the Holy Spirit, so that they could see Him not just as a simple man, but as the Son of God. The Taboric moment reveals the Apostles His face, human and divine at the same time.

We are truly legitimate to affirm that the feast of the Transfiguration shows us two great and important objectives: the first is related to the aim of the economy of salvation, which is seeing God in eternity (this vision will be given to us at the end of times); the second objective is related to the fact that the Holy Apostles had the joy of living this vision of God during their human life ${ }^{27}$.

\section{Conclusion}

The New Testament is the place where the face of God reverberates on the human face of Christ. Saint John the Evangelist says: "he that has seen me has seen the Father" (Jn 14:9). The Gospels only refer to the human face of Christ in two Biblical passages: the Transfiguration, when His face was shining like the sun, and during the Passions, when they spat in His face. This short study intended to reiterate two fundamental ideas: on the one hand, presenting the substitution of the face of Christ in the iconoclast period, and, on the other hand, the rediscovery of the human, still eternal, face of God, through the narration of two important moments in the economy of salvation - the Humanization of the Face and the Transfiguration of the Savior in the Orthodox Tradition and theology. These two important

26 Emilianos SimONOPETRITE, Cuvântări mistagogice la sărbători (Mystagogical Speeches on Feasts), rom.transl. by Agapie Corbu, Arad, Sfântul Nectarie Publishing House, 2016, p. 240.

${ }^{27}$ DeseILle, Placide, Cununa binecuvântată a anului creștin (The Blessed Wreath of the Christian Year), rom.transl. by Felicia Dumas, Iași, Doxologia Publishing House, 2015, pp. 597-598. 
Christian feasts are two important events in the history of salvation, which reverberate unconditionally in two iconographical events. To sum up, the icon has always been and will always remain the way in which the Orthodox Church wished to continue the engraftment of the Holy Face of Christ into the world to the end of times.

\section{References}

1. BACONSKY, Teodor, Facebook: Fabrica de narcisism (Facebook: The Factory of Narcisism), București, Humanitas Publishing House, 2015.

2. BULGAKOV, Serghei, Icoana și cinstirea sfintelor icoane (The Icon and the Veneration of the Holy Icons), rom.transl. by Paulin Lecca, București, Anastasia Publishing House, 2000.

3. DeSEILle, Placide, Cununa binecuvântată a anului creștin (The Blessed Wreath of the Christian Year), rom.transl. by Felicia Dumas, Iași, Doxologia Publishing House, 2015.

4. Emilianos Simonopetritul, Cuvântări mistagogice la sărbători (Mystagogical Speeches on Feasts), trom.transl. by Agapie Corbu, Arad, Sfântul Nectarie Publishing House, 2016.

5. Evdokimov, Paul, Arta icoanei, o teologie a frumuseții (The Art of the Icon, Theology of Beauty), rom.transl. Grigore Moga, București, Sophia Publishing House, 2014.

6. ICĂ, Ioan I. jr., "Misterul Feței lui Hristos în tradiţia ortodoxă" (The Mystery of Christ's Face in the Orthodox Tradition), in the volume Omagiu Părintelui academician Dumitru Popescu (Homage to Reverend Father academician Dumitru Popescu), Alba Iulia, Reîntregirea Publishing House, 2005.

7. Saint John of Damascus, Cultul sfintelor icoane (The Veneration of the Holy Icons), rom.transl. by Dumitru Fecioru, București, Tipografia Cernica, 1937.

8. MondZAIN, Marie-José, Imagine, icoană, iconomie (Image, icon, iconomy), rom.transl. by Adrian Alexandrescu, București, Sophia Publishing House, 2009.

9. REMETE, George, "Ființa și credința" (The Faith and the Being), in the volume Ideea de ființă (The Idea of Being), București, Academia Română Publishing House, 2012.

10. SCHÖNBORN, Christoph, Icoana lui Hristos (The Icon of Christ), 
rom.transl. by Vasile Răducă, București, Anastasia Publishing House, 1996.

11. ŠPIDLíK, Tomáš, Credință și icoană (Faith and Icon), rom.transl. by Ioan Milea, Cluj Napoca, Dacia Publishing House, 2002.

12. StăniloAe, Dumitru, Teologia Dogmatică Ortodoxă (The Orthodox Dogmatic Theology), vol. III, Fourth Edition, București, Institutul Biblic și de Misiune Ortodoxă Publishing House, 2010.

13. Saint Theodore the Studite, Iisus Hristos-Prototip al icoanei Sale (Jesus Christ-Prototype of His Icon), rom.transl. by Ioan I. Ică jr., Alba Iulia, Deisis Publishing House, 1994.

14. OUSPENSKY, Leonid, "Icoana, vedere a lumii duhovnicești" (The Icon, Vision of the Spiritual World), in the volume Ce este icoana? (What is the Icon?), rom.transl. by Vasile Manea, Alba Iulia, Reîntregirea Publishing House, 2005.

15. OUSPENSKY, Leonid, Teologia icoanei în Biserica Ortodoxă, rom.transl. by Teodor Baconsky, București, Anastasia Publishing House, 2009. 